\title{
Solar Trigeneration: a Transitory Simulation of HVAC Systems Using Different Typologies of Hybrid Panels
}

\author{
Alejandro del Amo Sancho \\ Mechanical Department \\ Universidad de Zaragoza, Zaragoza, Spain \\ e-mail: adelamo@unizar.es
}

Cite as: del Amo Sancho, A., Solar Trigeneration: a Transitory Simulation of HVAC Systems Using Different

Typologies of Hybrid Panels, J. sustain. dev. energy water environ. syst., 2(1), pp 1-14, 2014, DOI: http://dx.doi.org/10.13044/j.sdewes.2014.02.0001

\begin{abstract}
The high energy demand on buildings requires efficient installations and the integration of renewable energy to achieve the goal of reducing energy consumption using traditional energy sources. Usually, solar energy generation and heating loads have different profiles along a day and their maximums take place at different moments. In addition, in months in which solar production is higher, the heating demands are the minimum (hot water is consumed only domestically in summer). Cooling machines (absorption and adsorption) allow using thermal energy to chill a fluid. This heat flow rate could be recovered from solar collectors or any other heat source. The aim of this study is to integrate different typologies of solar hybrid (photovoltaic and thermal) collectors with cooling machines getting solar trigeneration and concluding the optimal combination for building applications. The heat recovered from the photovoltaic module is used to provide energy to these cooling machines getting a double effect: to get a better efficiency on PV modules and to cool the building. In this document the authors analyse these installations, their operating conditions, dimensions and parameters, in order to get the optimal installation in three different European cities. This work suggests that in a family house in Madrid, the optimal combination is to use CPVT with azimuthally tracking and absorption machine. In this case, the solar trigeneration system using $55 \mathrm{~m}^{2}$ of collector area saves the cooling loads and $79 \%$ of the heating load in the house round the year.
\end{abstract}

\section{KEYWORDS}

Hybrid collectors, Solar cooling, Solar trigeneration, CPVT, PVT, Performance evaluation

\section{INTRODUCTION}

Energy savings on building applications and renewable energy technologies are two very close concepts. European regulations, like 2002/91/CE [1], are promoting energy savings in buildings through energy certificates which has been its refunded with 2010/31/UE [2] defining "Nearly Zero Energy Buildings". With the aim to reduce the energy use in buildings, it is necessary to use high efficiency installations. Several installation typologies with high efficiency are recently built, but some new installations (like geothermal, micro trigeneration, solar trigeneration, etc.) have been researched and developed, to increase the efficiency of the systems. In this work, the authors propose a comparison between some high efficiency installations.

In summer, when irradiation is high, heating demands are low, and in winter the opposite happens. Absorption and adsorption machines allow the use of the heat flow to cover cooling loads. Combining these technologies with solar thermal collectors we obtain 
the concept of solar cooling. In the Mediterranean climates, solar installations have many problems under summer working conditions due to the high temperatures reached in collectors. These problems may be solved using this heat flow with an absorption (or adsorption) machine. On the other hand, solar hybrid panels produce simultaneously electricity and heat which can be combined with a cooling machine, getting solar trigeneration. This hybrid system could provide the building heating and cooling loads and electricity needed in a house.

A relevant difference between an adsorption and an absorption machine is in the hot side inlet temperature coming from the collectors. Usually, absorption machines require higher temperature to work properly. Moreover, absorption machines usually have a better coefficient of performance (COP) than adsorption ones. Both machines can operate at partial loads, so a thorough study under transient conditions must be done to conclude which machine and working conditions are the more suitable depending on each climate.

Moreover, different collector typologies can be used to provide heat flow to these cooling machines. Depending on the temperature required by each machine and the partial working conditions, flat plate or concentrating hybrid collectors may be the more appropriate choice.

This study combines hybrid panels with solar cooling to get solar trigeneration system. The aim of this work is to evaluate this installation in different locations in Europe. This installation has been evaluated comparing different typologies of hybrid panels (flat plate and parabolic collectors) and different cooling machines. The transitory simulation with TRNSYS allows one to analyse the working conditions and to optimize all components in the installation (the storage tanks, solar surface, and all components in the installation).

Solar cooling has been well documented by some authors like Desideri et al. [3]. In the present document the integration of different hybrid collectors will provide more results about these installations. With this study, an optimal size of each component is found for a single-family house placed at different locations in Europe. The comparison among different typologies of panels will conclude the optimal combination for each location. The electrical efficiency in the photovoltaic cell is improved due to the cooling effect. Benefits will be evaluated, as well as working conditions using constant flow pumps and variable flow pumps.

Since the beginning of the integration of solar thermal technology on buildings in Mediterranean climates, some troubles have occurred. One of the most important is the stagnation temperature on the panels, which represents the maximum temperature reached with zero flow of the coolant. This situation occurs in the summer, when high irradiation and low demand take place at the same time. For this reason, in these climates it is interesting to use collectors with high convection losses at high temperatures. This means that a collector with high thermal loss coefficients $\left(a_{1}\right.$ and $\left.a_{2}\right)$ will protect itself from these high temperatures in the summer.

Hybrid collectors which produce thermal energy and electricity at the same time, have been researched and documented by several authors like Chow [4], Ibrahim et al. [5] and Assoa et al. [6]. Photovoltaic modules produce around $6-15 \%$ of electricity (depending on the technology used), 5\% is reflected, and the rest is lost as thermal energy. This thermal energy can be captured with a heat recovery system to be used in thermal applications. At the same time, the cooling effect in the solar module increases the collector efficiency (electrical and thermal). The opposite effect occurs when the application works at high temperatures, which will cause a negative effect on photovoltaic production. For cooling machines (absorption or adsorption machines), a high input temperature is required. For this reason, the hybrid collector typology will depend on the cooling machine inlet temperature. 
Hybrid panels have been researched since the 80's, but are still in a state of constant development. From all existing typologies, we have selected the two most representative collectors: flat plate hybrid collector (PVT) and concentrating hybrid collectors (CPVT). Although hybrid collectors can be cooled with air or water, we have used water because it has better cooling effect in the heat recovery.

The flat plate collectors (PVT) have also several typologies as reviewed in Charalambous et al. [7], Dupeyrat et al. [8] and Dubey and Tiwari [9]. The panel considered in this work is a conventional photovoltaic module in which a copper heat recovery (sheet and tube) is installed on the back surface and an insulating layer is placed between this heat exchanger and the ambient. The module used to manufacture the PVT panel evaluated is a conventional model, with $180 \mathrm{~W}$, and a temperature power coefficient of $0.45 \% / \mathrm{K}$. Thermal characteristics have been developed from the following equation already developed by Duffie and Beckmann [10]:

$$
\eta=\frac{Q_{u}}{A * I_{T}}=F_{R}(\tau \alpha)_{n}-F_{R} U_{L} \frac{\left(T_{i}-T_{a}\right)}{I_{T}}-F_{R} U_{L / T} \frac{\left(T_{i}-T_{a}\right)^{2}}{I_{T}}
$$

On this equation, the main parameters $F_{R}$ (heat removal efficiency coefficient) and $U_{L}$ (heat loss coefficient) are 0.79 and $7.23 \mathrm{~W} / \mathrm{m}^{2} \mathrm{~K}$ respectively, which have been theoretically calculated. Usually, technical data sheets of thermal collectors contain two coefficients $\left(a_{1}\right.$ and $a_{2}$, calculated from $F_{R}$ and $U_{L}$ ) which represent how efficiency varies when the collector temperature changes. From, the PVT collector properties, calculating $F_{R}$ and $U_{L}$ parameters, we obtain the optical and thermal parameters with which thermal generation will be calculated. These parameters are: $\eta_{\mathrm{o}}=0.62, a_{1}=5.73 \mathrm{~W} / \mathrm{m}^{2} \mathrm{~K}, a_{2}=0.00374 \mathrm{~W} / \mathrm{m}^{2} \mathrm{~K}^{2}$ and its correspondent efficiency curves are represented in Figure 1.

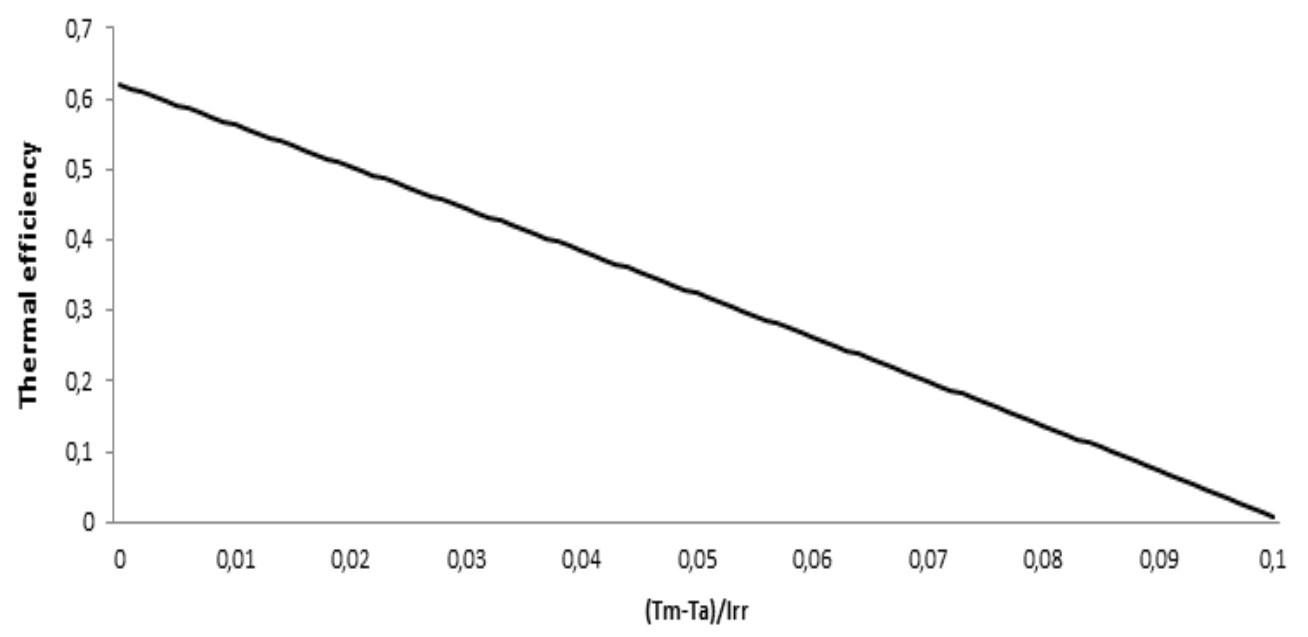

Figure 1. Thermal efficiency of a PVT (photovoltaic and thermal) panel

$T_{m}$ is average temperature of the collector, $T_{a}$ is ambient temperature and $I_{r r}$ is irradiation. Concentrating hybrid collectors (CPVT) will obtain higher temperatures than flat plates. Previous studies like Mittelmann et al. [11] analyse its efficiency. On this work, a commercial collector has been evaluated [12]. This hybrid collector has a surface of $6 \mathrm{~m}^{2}$, concentrating ratio of 10 times, the photovoltaic cell has a short circuit current $\left(I_{s c}\right)$ of $13 \mathrm{~A}$, an open circuit voltage $\left(V_{o c}\right)$ of $51 \mathrm{~V}$, maximum power point current $\left(I_{m p p}\right)$ of $12.5 \mathrm{~A}$, a maximum power point voltage $\left(V_{m p p}\right)$ of $40 \mathrm{~V}$ and a power temperature coefficient $(\gamma)$ of 
$0.4 \% /{ }^{\circ} \mathrm{C}$. CPVT collectors will not have this problem with the stagnation temperature due to the one axis (zenith) movement. In Figure 2 the CPVT studied is shown.

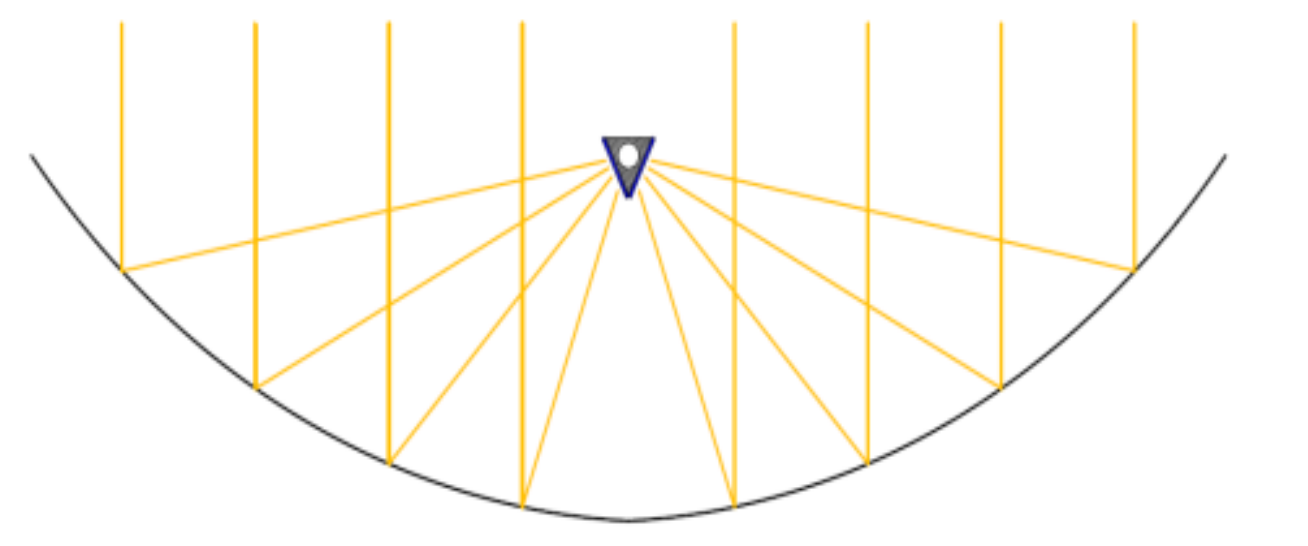

Figure 2. CPVT collector

\section{SOLAR COOLING USING HYBRID COLLECTORS}

Several installations combine thermal sources with absorption and adsorption machines like [13-15], and authors like Mittelmann et al. [11] use solar energy to activate these cooling machines. As Garcia concludes in [16] or Bermejo et al. study in Sevilla [17], solar cooling has an interesting application in Spain. The concept termed Solar Trigeneration can be achieved in different ways. Particularly, in this work it is obtained combining solar hybrid collectors with cooling machines (like absorption and adsorption). On this installation the solar cogeneration produces electricity and heat. This heat flow is used for domestic hot water or heating applications during winter and providing energy to a cooling machine in summer for air conditioning demands.

This paper aims to compare different solar hybrid collectors (PVT vs. CPVT) when they are combined with cooling machines (absorption vs. adsorption). Initially, absorption machines require higher temperatures than adsorption machines (between $85-95^{\circ} \mathrm{C}$ and 70 $-85^{\circ} \mathrm{C}$ respectively). Because of these conditions, and because the thermal efficiency in solar panel decreases when the operating temperature rises, it seems logical to use an adsorption machine. Otherwise, absorption machines have better COP than adsorption machines. Hence, adsorption machines require more energy to work and consequently more collector surface. Comparing hybrid collectors, only concentrating technology like CPVT can use the direct irradiation instead of the global irradiation which flat plate panels like PVT capture. Also, CPVT needs at least one axis tracking system, but thermal efficiency is higher than PVT panels at high temperatures. For all these concepts, in the following part we will quantify the optimum combination from the thermal efficiencies, COP and photovoltaic efficiency.

As Lecuona et al. explain in [18] the operating temperature of absorption machines is the main factor to determine the COP. To make a transient evaluation, it is necessary to consider the COP of the cooling machine at partial loads. Using the model developed using the software EES (Fig. 3) it is possible to evaluate this effect. On it, the temperatures in the generator $\left(T_{G}\right)$, evaporator $\left(T_{O}\right)$ and condenser $\left(T_{K}\right)$ are modified. 


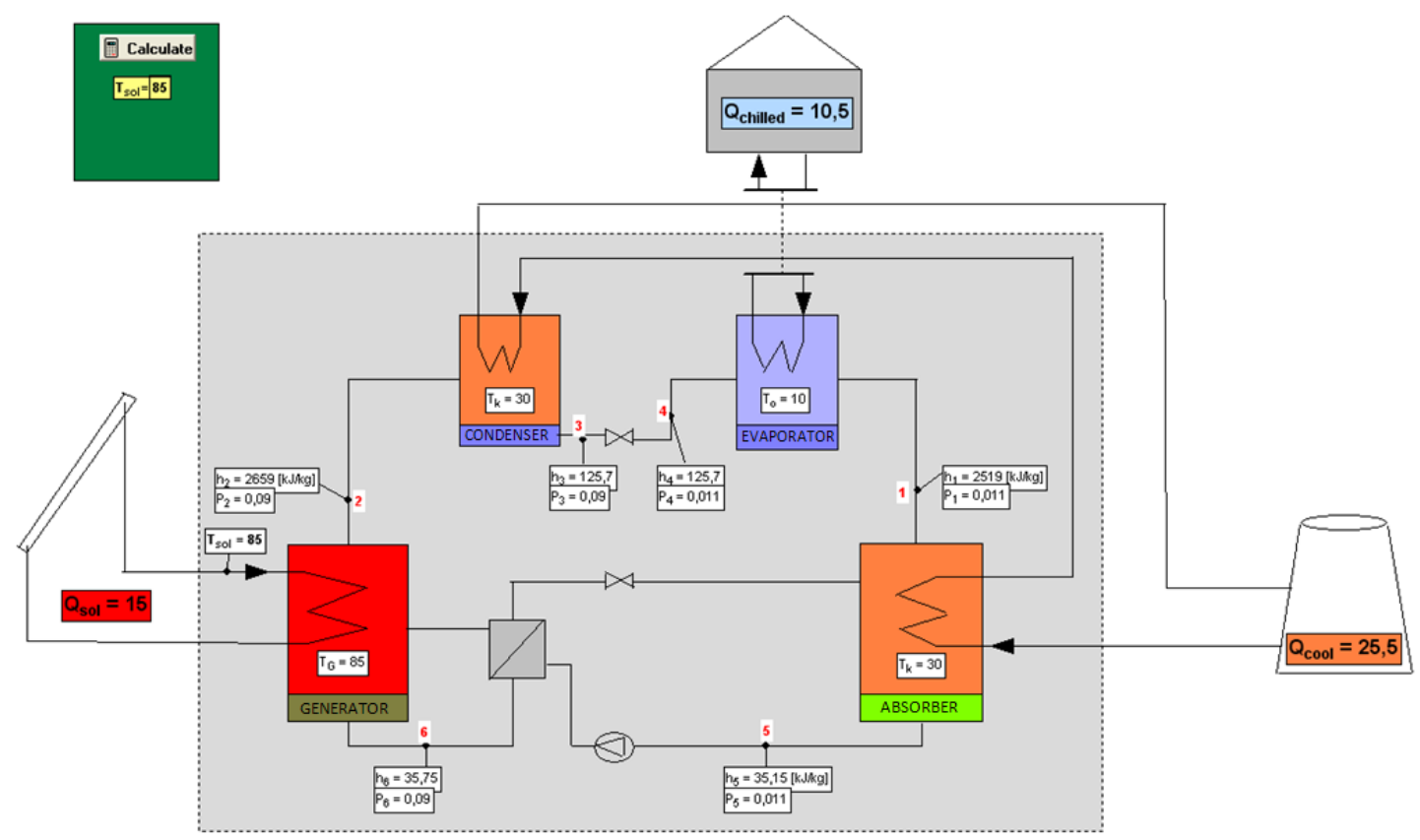

Figure 3. EES absorption machine model

As the Figures 4 - 6 show, the cooling machine performance increases when $T_{G}$ is increased, when $T_{K}$ is reduced and $T_{O}$ is increased. Also, these figures show that it is more effective to reduce the temperature in condenser $\left(T_{K}\right)$ by one degree than increasing by one degree in the generator or evaporator. The cooling machine efficiency $\left(\varepsilon_{C M}\right)$ can be defined as the Equation 2 taken from [19]:

$$
\varepsilon_{C M}=\frac{T_{G}-T_{K}}{T_{G}} * \frac{T_{O}}{T_{K}-T_{O}}
$$

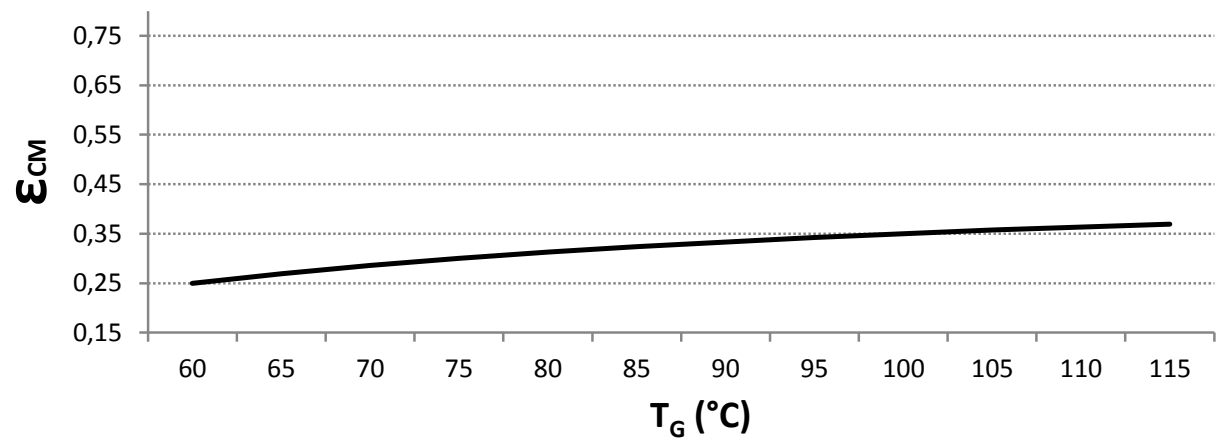

Figure 4. Cooling machine efficiency vs. $T_{G}$

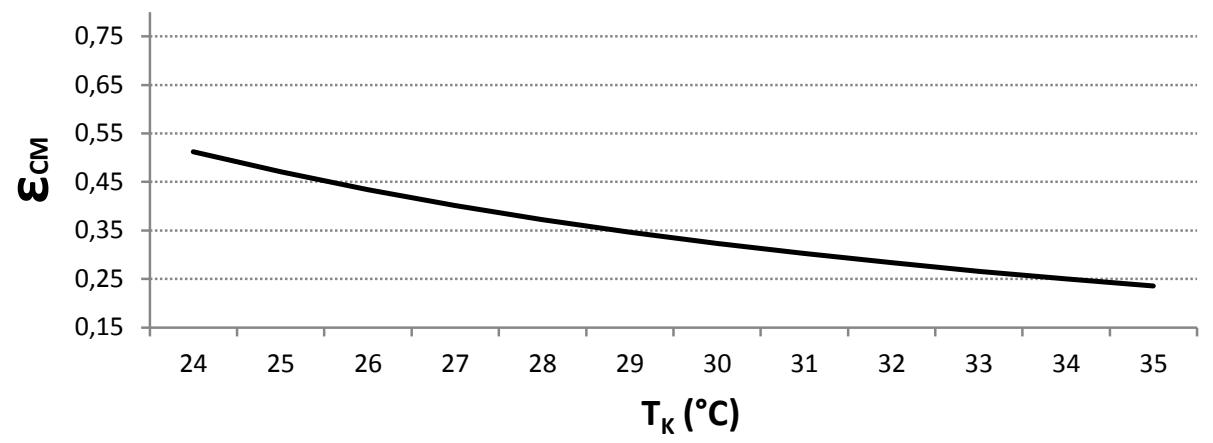

Figure 5. Cooling machine efficiency vs. $T_{K}$ 


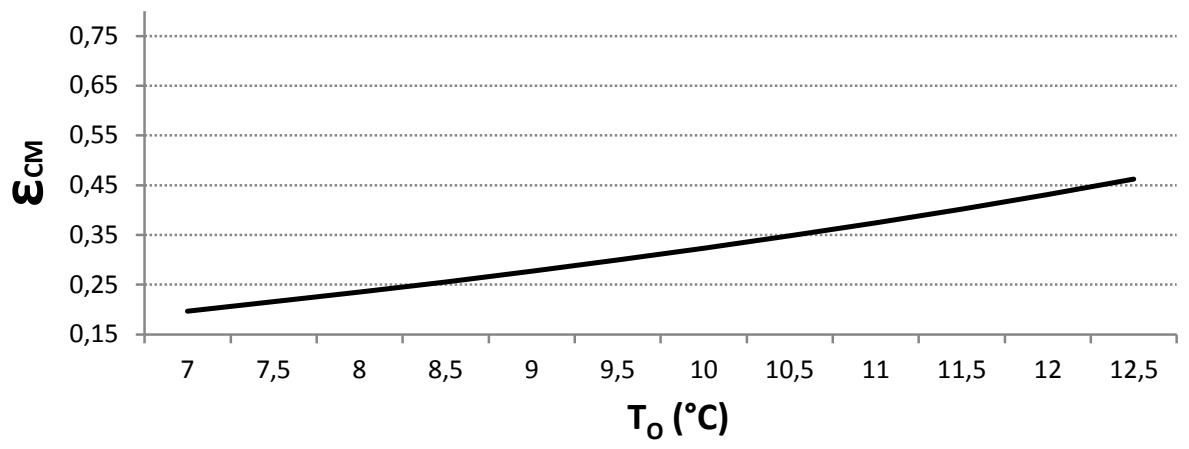

Figure 6. Cooling machine efficiency vs. $T_{O}$

$T_{G}$ depends directly on the fluid inlet temperature coming from the solar collectors, and this temperature also affects the collector efficiency and its value determines the global efficiency of the installation. The environment (humidity and temperature) has an important influence on the $T_{K}$ and warm climates are not adequate for these installations because the cooling tower cannot work as needed. Depending on the system used to cool the buildings, the efficiency will be different. For example, using fan-coils $T_{O}$ is around $7-15^{\circ} \mathrm{C}$, or using low cooling fans around $15-17^{\circ} \mathrm{C}$, with cooling ceilings around $15-18$ ${ }^{\circ} \mathrm{C}$, with concrete core activation $16-19^{\circ} \mathrm{C}$, or with floor/wall cooling around $17-22{ }^{\circ} \mathrm{C}$. Therefore, this temperature has influence on the global efficiency of the installation.

This $\mathrm{LiBr}$ absorption machine works with a refrigerant fluid (water) which has been simulated with Termograf software, in order to have a more accurate estimation and its diagram process, which is represented on Figure 7.

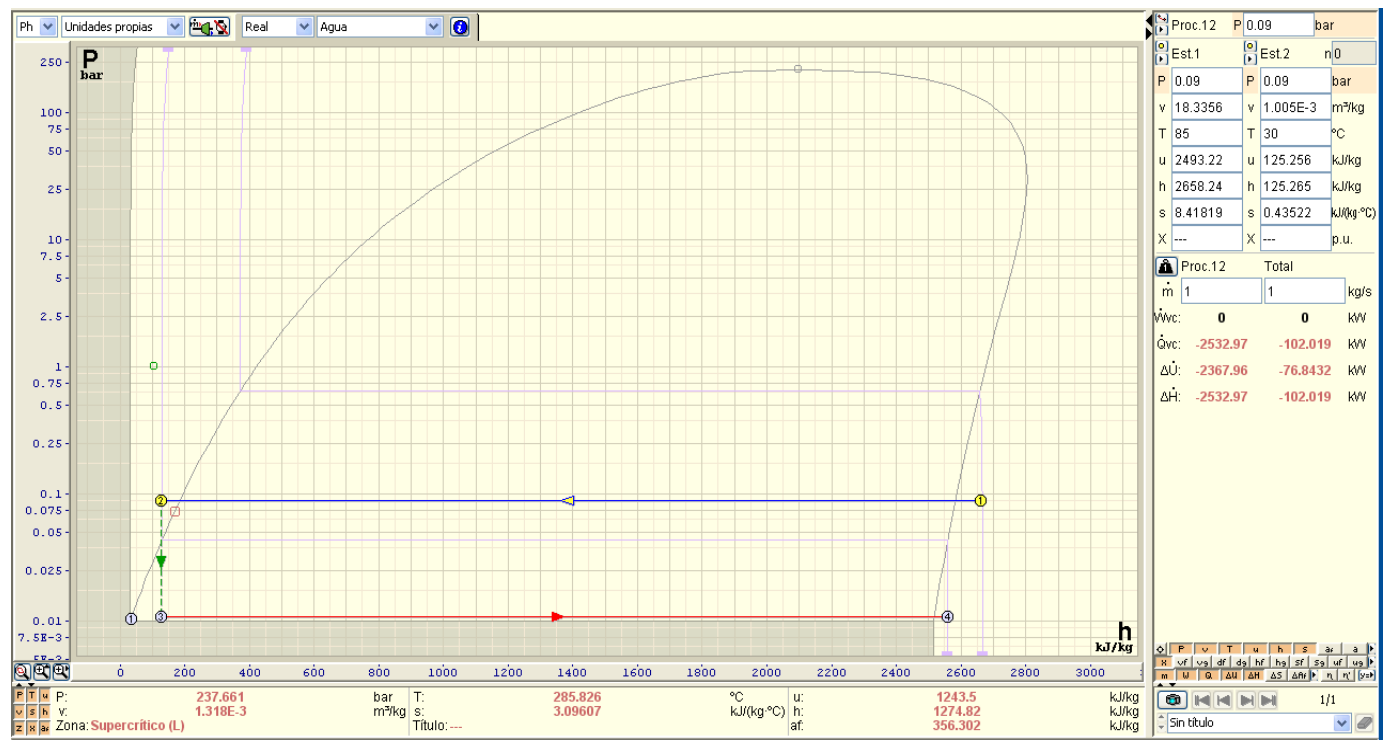

Figure 7. Refrigerant cycle calculated with Termograf

In the following parts both cooling machines, absorption and adsorption, are simulated with both collectors. To make the transient simulation, all installation has been simulated with TRNSYS, and several conclusions are taken accordingly.

Figure 8 shows the first option, where PVT panels provide a heat flow rate to an adsorption machine. Starting from the weather generator, located in Madrid, PVT panels (tilted $10^{\circ}$ ) heat the water storage tank. These tanks provide energy to a $15 \mathrm{~kW}$ adsorption machine which chills the cool storage tank. Both heat flow rates are dissipated through 
the cooling tower at the top of the figure. The first criterion is to design the hot tank with twice the capacity of the cool tank.

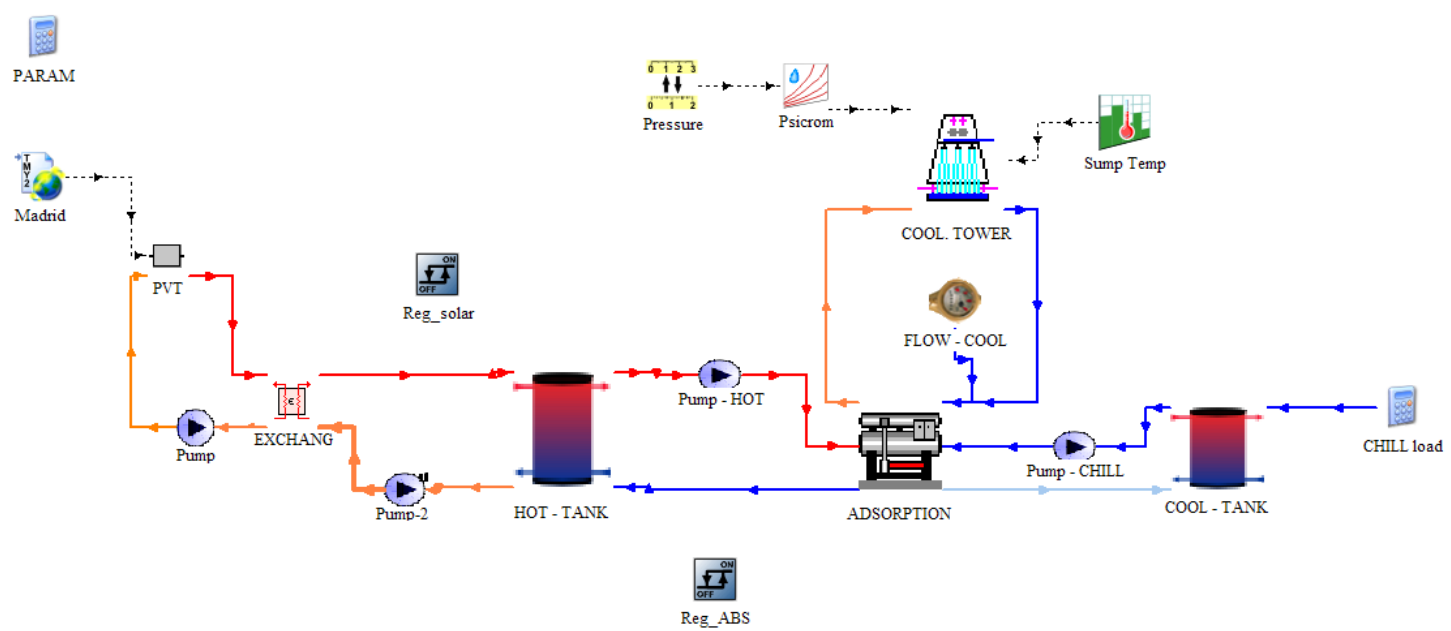

Figure 8. TRNSYS scheme - PVT with adsorption machine

To provide the energy required by this cooling machine, there are $70 \mathrm{~m}^{2}$ of PVT collectors. Installing more collector surface will reduce the photovoltaic efficiency because the operating average temperature in the panel would be higher. This happens because the energy not provided to the cooling machine is used to increase the cell temperature. On the contrary, less collector surface means that there is not enough power in the beginning of the day which would cause intermittent working conditions. Consequently, when the solar regulator activates the pump, the flow is enough to decrease the collector temperature stopping the pump. This problem can be easily solved with a variable flow pump, with which the collector surface can be reduced by $10 \%$. The optimal hot storage tank volume in this case is $3 \mathrm{~m}^{3}$ and for the cool storage tank, $1.5 \mathrm{~m}^{3}$. Higher capacities means more time to heat the hot storage tank and less volume could saturate the storage tank capacity in some periods in summer days. This saturation means that the hot tank temperature will reach its upper maximum limit (around $95^{\circ} \mathrm{C}$ ) and the panels will increase their temperature with a reduction in the photovoltaic generation. If the installation has thermal dissipation, this temperature won't be too high, but it will cause an additional electrical consumption. In this case the energy used to dissipate the unnecessary heat is approximately a $15 \%$ of the increased energy in the cooling effect.

Figure 9 represents during a day the thermal power generated in the collector, photovoltaic generation, heat flow rate to the adsorption machine and chilled energy supplied by it. As shown in this figure, the collectors provide energy to the storage tank from 8 AM until 4 PM, but adsorption machine is stopped by $12 \mathrm{PM}$, when cooling load is required on this day. In the beginning of the day there are some oscillations (as seen in Figure 9). This problem can be solved with a variable speed pump. Figure 10 represents the most significant efficiencies in this installation like thermal efficiency and photovoltaic efficiency in the collector and the coefficient of performance (COP). As can be seen, at the start of the cooling machine (at 12 noon), the thermal and photovoltaic efficiencies increase. In the same way, too much collector surface causes high temperatures (saturation) in the hot storage tank. These high temperatures take place because the cooling machine has a maximum power rate, and at the same time, the energy supplied by the panels to the hot storage tank is higher than the energy supplied by the storage tank to this cooling machine. Due to this energy imbalance, the hot tank heats up until $95{ }^{\circ} \mathrm{C}$, and in this moment the solar circuit regulation stops the pumps. 
Consequently, the panel reaches high temperatures and the photovoltaic cell efficiency decreases.

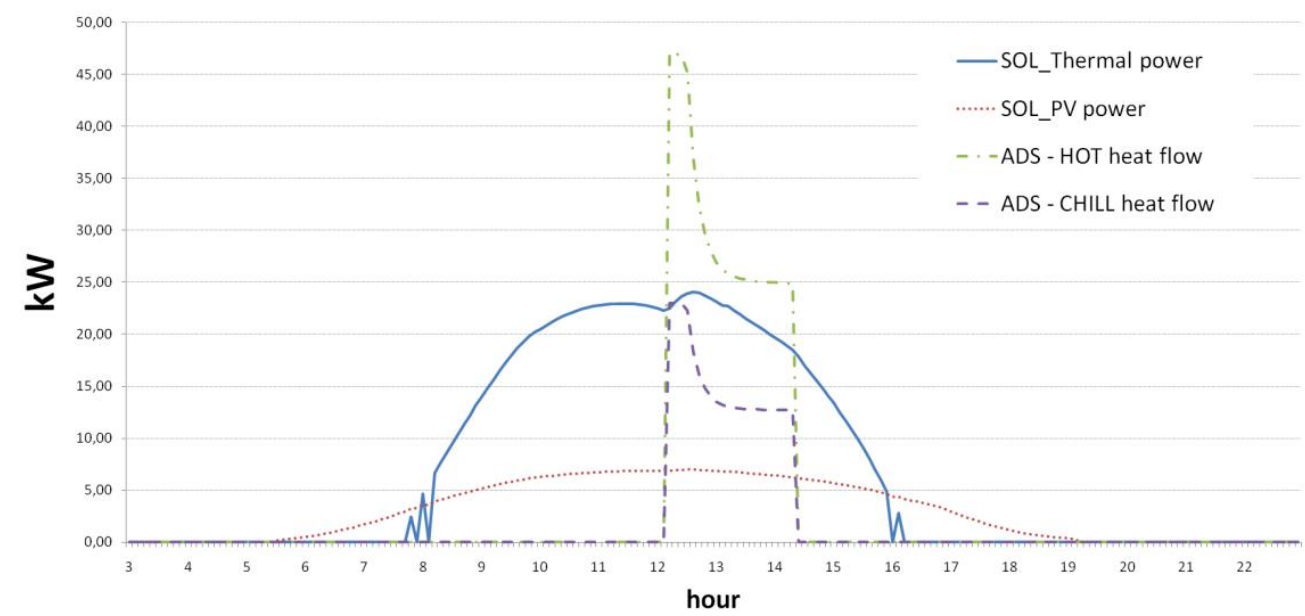

Figure 9. Daily heat flow profiles for ADS machine with PVT

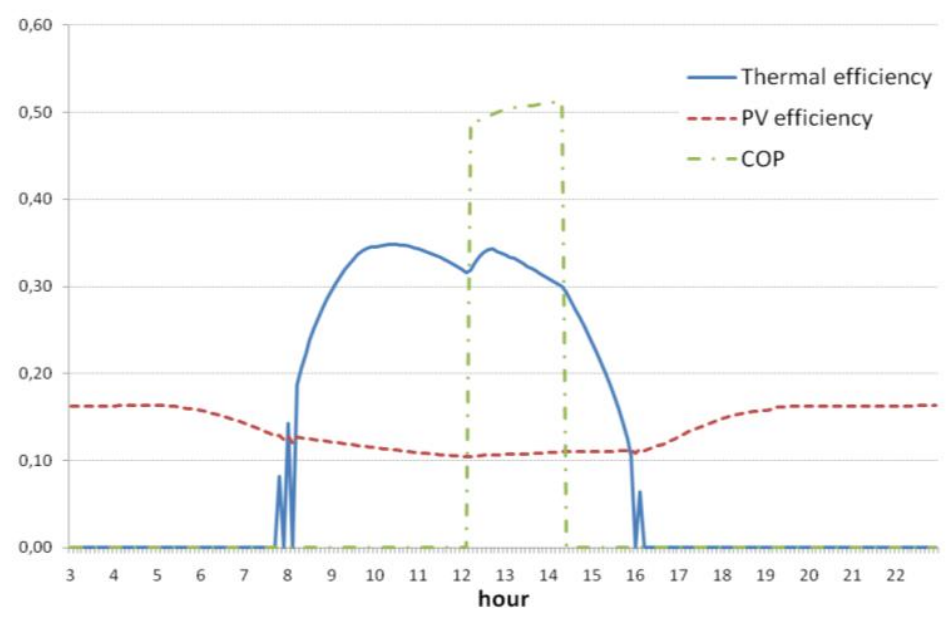

Figure 10. Installation efficiencies

The second study combines adsorption machine with CPVT. In this installation an azimuthal axis has been used, with a surface of $55 \mathrm{~m}^{2}$ and a storage tank capacity of $3 \mathrm{~m}^{3}$. With this collector there are no oscillations since irradiation in the collector is higher in the morning due to the incident angle. Figure 11 represents the energy daily profiles using CPVT collectors.

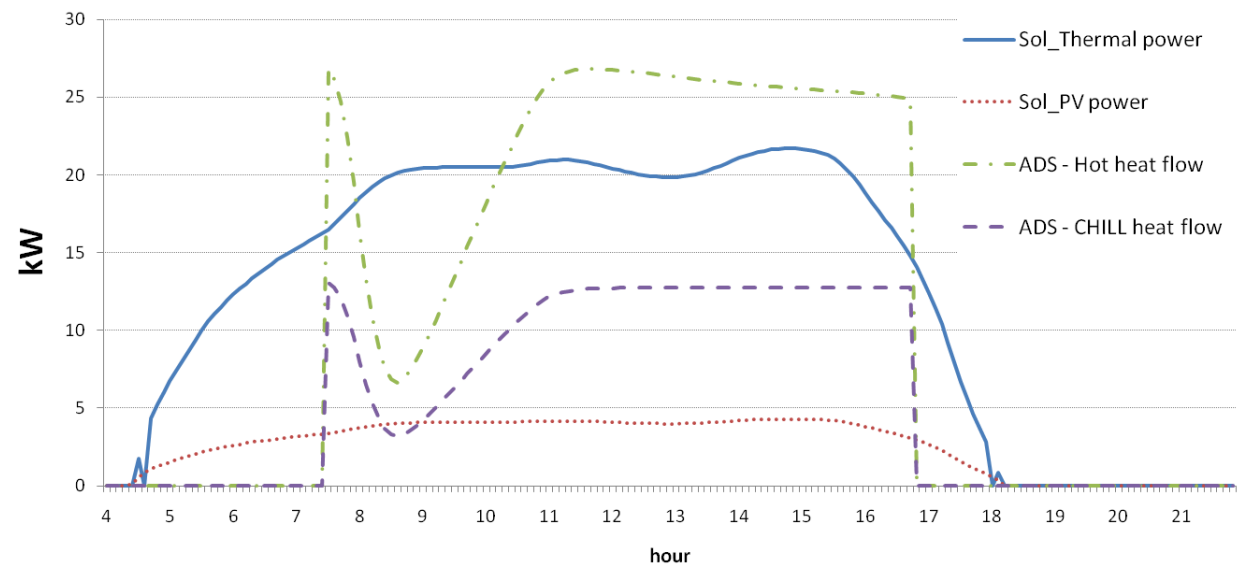

Figure 11. CPVT with adsorption machine heat flow daily profiles 
An important difference between both collectors is that CPVT collectors have one axis tracker. This movement allows the capture of more irradiation at the beginning and at the end of the day. Figure 12 shows the thermal efficiency in the collectors and represent this advantage for CPVT. In Figure 13, both photovoltaic efficiencies are represented and CPVT panels usually have better values. This better efficiency takes place because photovoltaic cells used in concentrating technology have three different layers with which efficiencies around 35\% can be achieved (much higher than $15-18 \%$ obtained in flat plate technology). Also, the thermal efficiency has better values at high temperatures (the thermal loss coefficient, usually called $a_{l}$, is lower), so it is an interesting combination with cooling machines. This photovoltaic technology is used only in concentrating collectors due to its higher price. The regulation used in the adsorption installation starts at $80{ }^{\circ} \mathrm{C}$. This is an important effect because the adsorption will not start until the storage tank reaches this temperature, and as shown in Figure 14, using PVT panels the installation starts later. Turning some degrees to morning orientations to capture more irradiation with PVT is not enough because the slope is very small $\left(10^{\circ}\right)$. Also, Figure 15 shows the difference between outlet temperatures in both solar collectors.

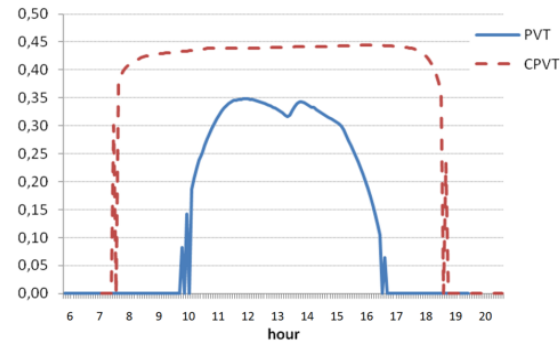

Figure 12. Thermal collectors efficiency daily profiles

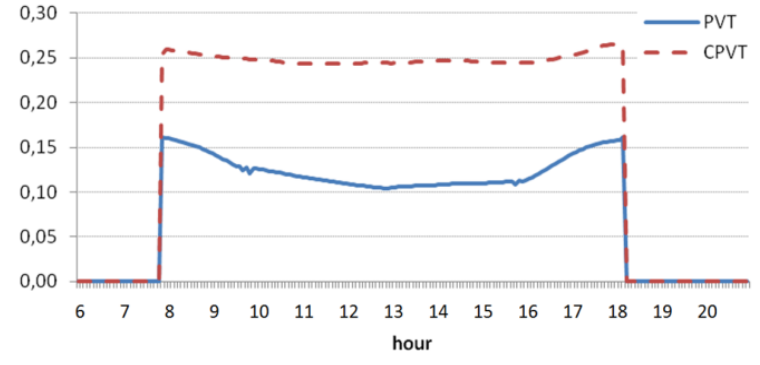

Figure 13. Photovoltaic collectors efficiency daily profiles

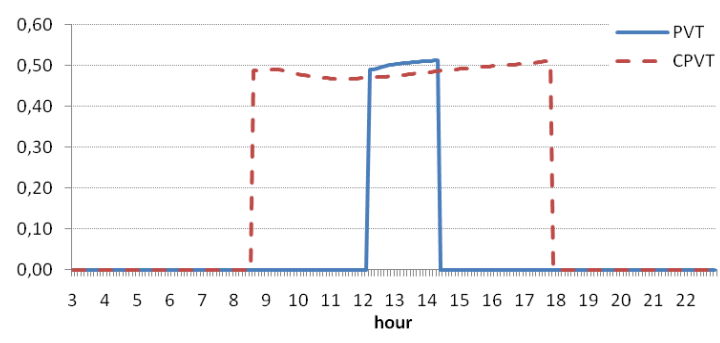

Figure 14. COP

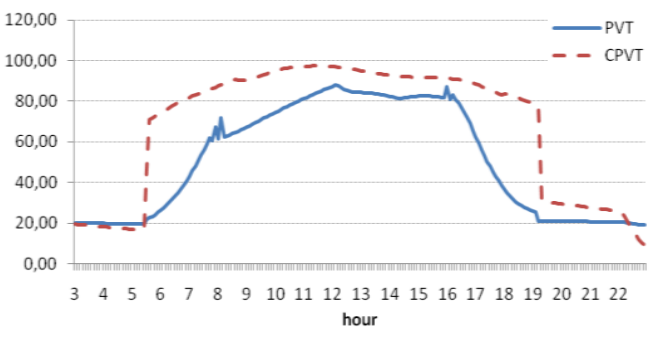

Figure 15. Solar output temperature

As explained before, absorption machines require higher temperatures than adsorption machines from collectors. This parameter $\left(T_{G}\right)$ will determine the overall efficiency because it determines the solar surface needed and the cooling capacity.

The first difference between absorption and adsorption machines is the COP. High values of this coefficient can reduce notably the collector surface, providing the same energy to cooling loads. Using $70 \mathrm{~m}^{2}$ of PVT collector with an absorption machine the chill power is higher than using an adsorption machine. This is due to COP difference although the thermal efficiency in the hybrid collector working at high temperatures is lower. Comparing both machines at $15 \mathrm{PM}$, absorption machine provides $18.63 \mathrm{~kW}$, and an adsorption machine $12.5 \mathrm{~kW}$. The conclusion is that using absorption machine with PVT panels the chill flow energy generated is higher. This means that, although a lower 
temperature is required for adsorption machine and consequently there is more efficiency in the collectors, the higher COP in absorption machines is more important.

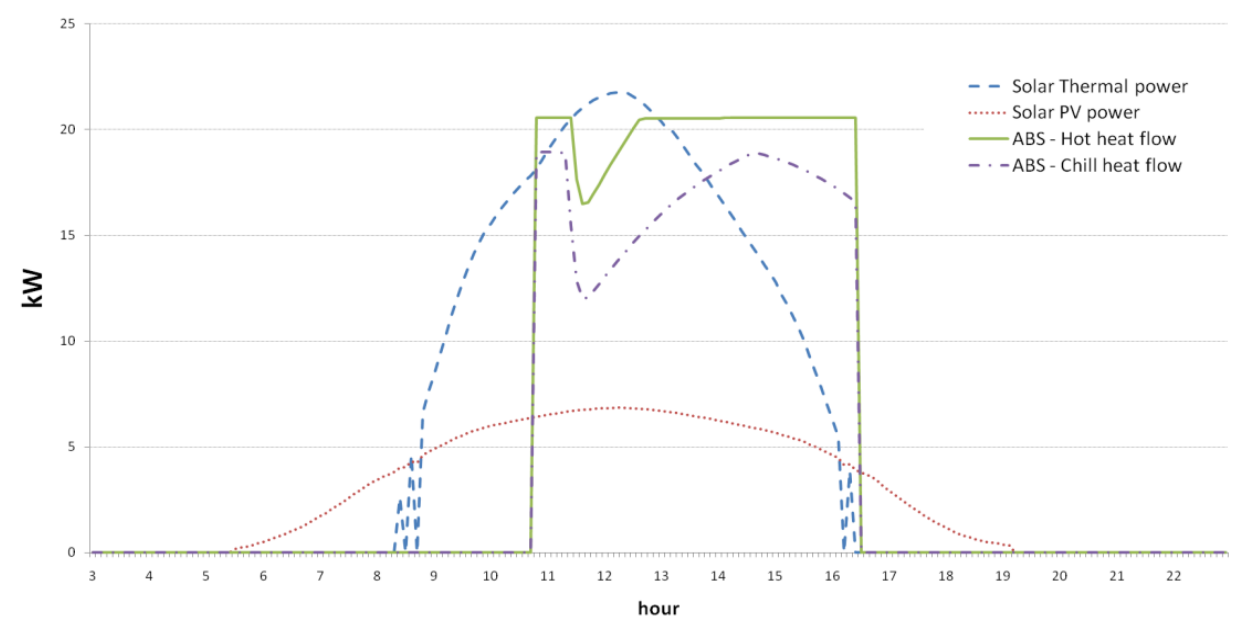

Figure 16. PVT with absorption machine heat flow daily profiles

Comparing the thermal efficiency in both collectors and machines there are three conclusions to highlight. The first one is that using PVT panels with absorption machines, thermal efficiency is lower than using adsorption machines, due to the higher temperature at which they work. On the other hand, CPVT collectors have lower differences working with both machines. Consequently, the second conclusion is that CPVT curves are more stable at temperature variations. The third difference is the required surface, $70 \mathrm{~m}^{2}$ with PVT and 55 $\mathrm{m}^{2}$ with CPVT. These effects are represented in the Figure 17.

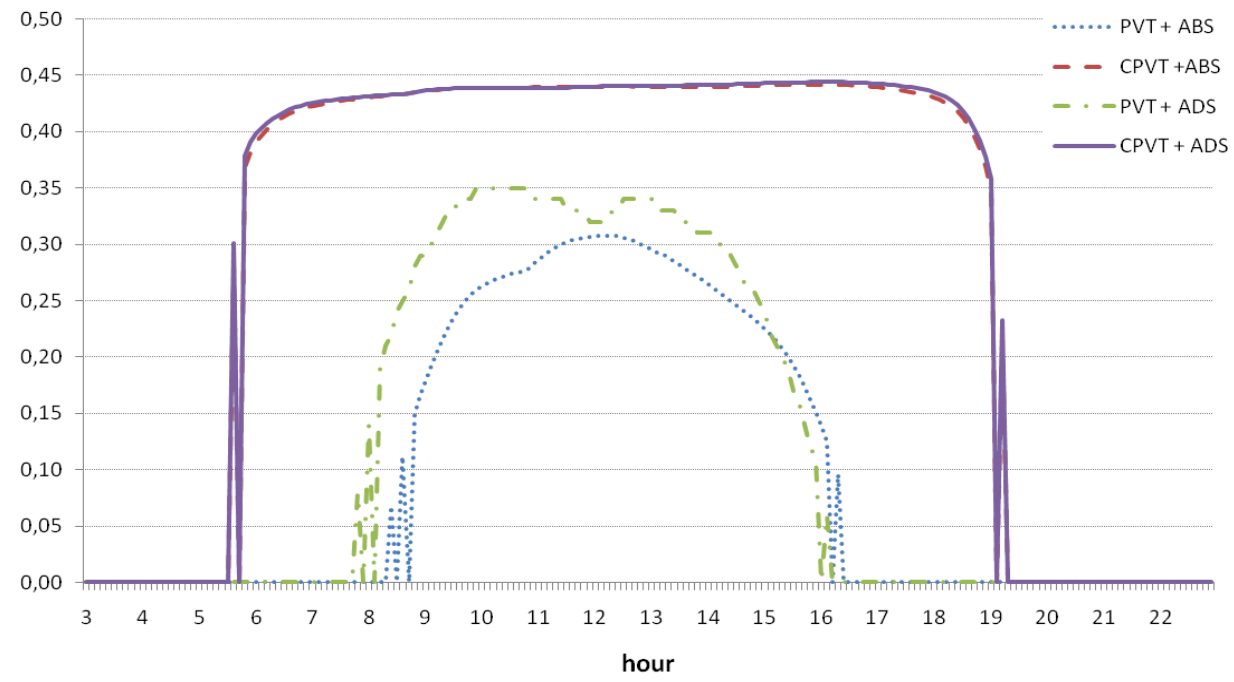

Figure17. Thermal efficiency of PVT and CPVT collectors combined with absorption and adsorption machines

From all cases studied in this paper several conclusions have drawn but, mainly there are two which must be highlighted. Using CPVT collectors, because of its required tracking system, there are higher irradiation levels in the morning and afternoon and they produce around 15\% more power (in Madrid) than PVT panels. Consequently less collector surface is needed. As it has been proposed initially, some questions must be resolved in this article: which combination between collectors and machines has better global efficiency? On one side, absorption machines have higher COP, and on the other 
side, these machines require higher temperatures and so the efficiency in the collectors is lower. As has been explained before, better COP is more significant in the absorption machines than the loss of efficiency in the collectors. Additionally, CPVT collectors are less affected by high temperatures. So the best combination is CPVT collectors with absorption machines and the collector area required is lower.

\section{SOLAR TRIGENERATION - YEARLY SIMULATION}

Once the optimal installation has been found, the following part studies the solar trigeneration during a year. Moreover this installation will be simulated at three different locations in Europe and the aim is to determine the optimal slope for the whole year using PVT collectors.

As concluded in the previous point, the most efficient installation is the one combining CPVT panels with absorption machine. Making a transient simulation (Figure 18) during summer with $55 \mathrm{~m}^{2}$ of collector, the hot storage tank temperature will not be below $75^{\circ} \mathrm{C}$. Consequently, it is not necessary to use a boiler to provide energy to the cooling machine, which would be completely inefficient. During winter, solar collectors (CPVT) contribute $79 \%$ of the heating load in a building located in Madrid, with a surface of $500 \mathrm{~m}^{2}$ and with a wall thermal transmittance of $0.66 \mathrm{~W} / \mathrm{m}^{2} \mathrm{~K}$. The same system placed in Stuttgart reduces to $18 \%$ of heating load, and a $15 \%$ in Stockholm. Hence, the proposed objective of reducing the GHG emissions has been achieved due to the high efficiency of this installation and the solar energy contribution.

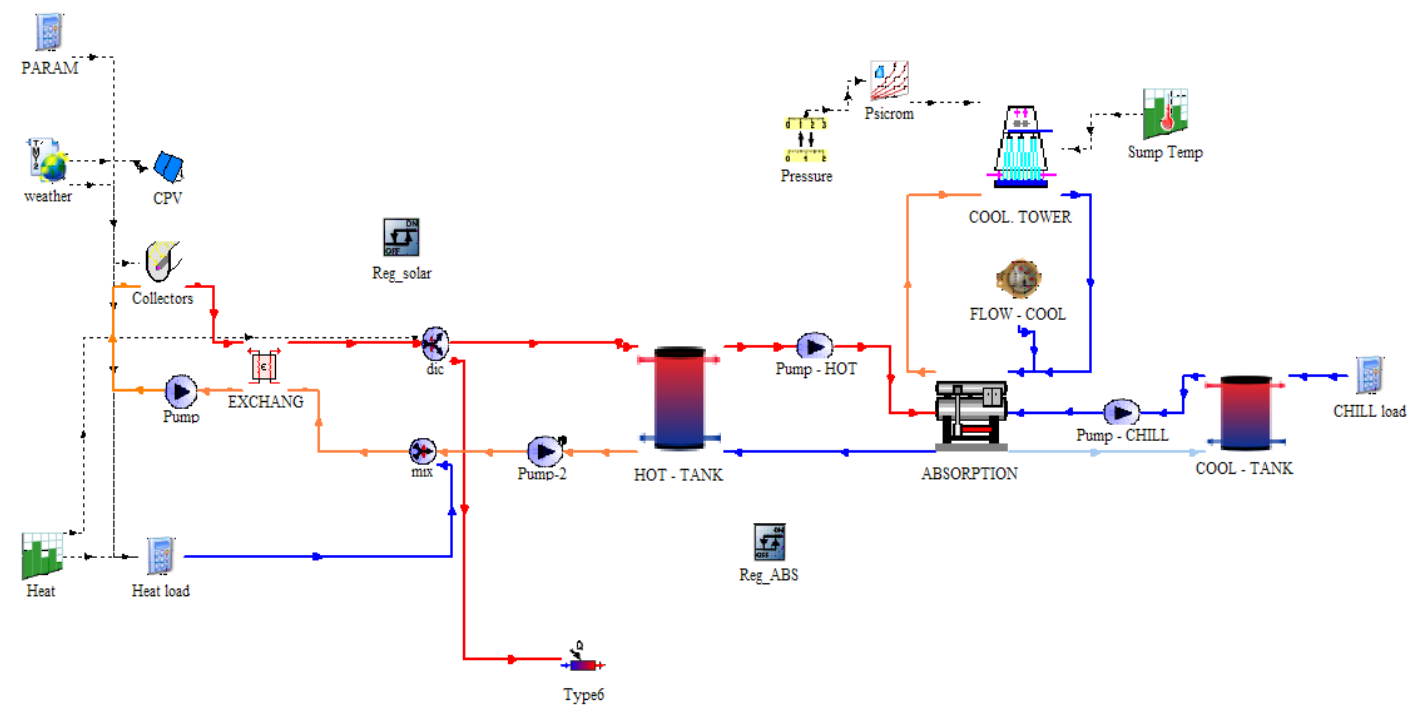

Figure 18. Heating and cooling scheme using CPVT and absorption machine

This installation covers all cooling loads with a slope of $10^{\circ}$ and a high percentage of heating load in Madrid. To optimize the installation in winter, the tilt must be $50^{\circ}$ in Madrid, $65^{\circ}$ in Stuttgart and $70^{\circ}$ in Stockholm.

Table 1 summarizes the results obtained in the simulations. First of all, energy savings in building heating loads are represented, and secondly, the optimum angle at which the collectors must be installed to get the maximum energy in the winter is shown. The installation covers all cooling loads with $55 \mathrm{~m}^{2}$ collector surface, tilted by $35^{\circ}$. 
Table 1. Heating results resume

\begin{tabular}{lccc}
\hline & Madrid & Stuttgart & Stockholm \\
\hline Heating savings & $79 \%$ & $18 \%$ & $15 \%$ \\
Heating optimum angle & $50^{\circ}$ & $65^{\circ}$ & $70^{\circ}$ \\
\hline
\end{tabular}

This difference between summer and winter tilt brings a conclusion. It is more efficient to install CPVT collectors with azimuthal tracking than zenith axis. Figure 19 represents the beam irradiation incident on a surface with one axis tracking, located in Madrid. This figure shows that a collector with azimuthal axis obtains more energy in the morning and in the afternoon than a collector with a zenith axis. Because of this increment of energy, using an azimuthal axis, the cooling machines can start to operate earlier, and collector surface can be reduced to provide the same energy.

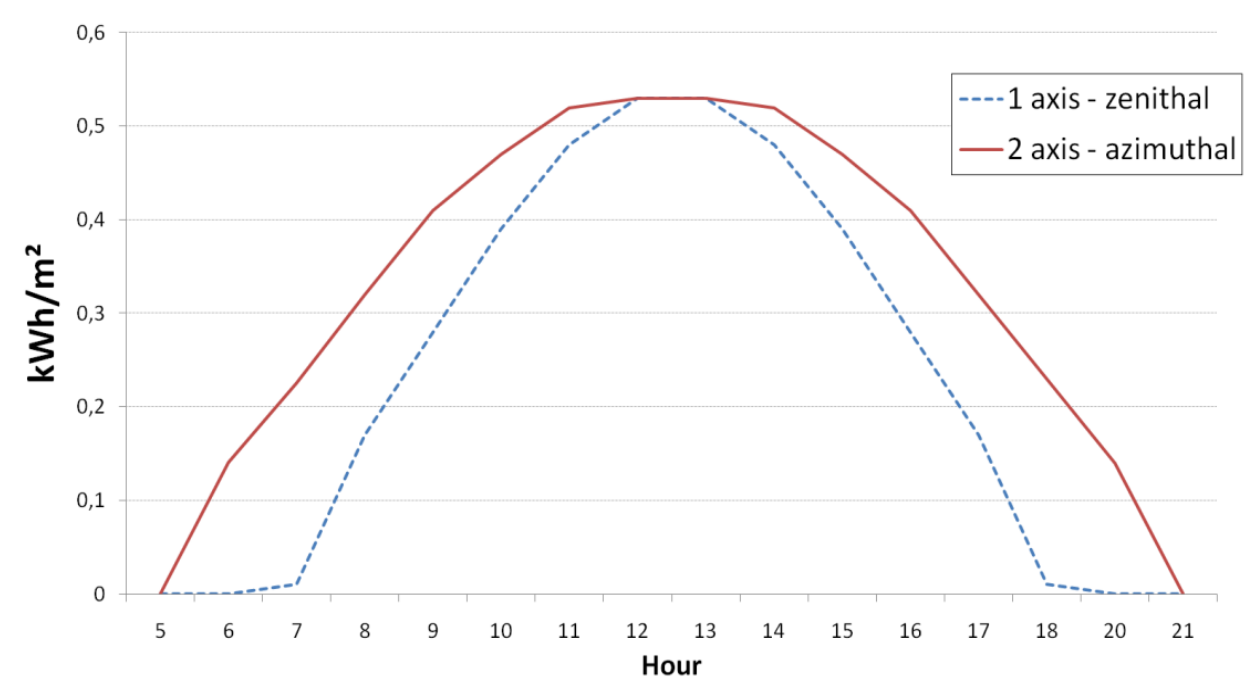

Figure 19. Irradiation daily profiles using zenithal or azimuthal axis

The energy lost during the first hours in the morning and during the last hours in the afternoon is not as important as lost collector surface in the winter because of the tilted surface. As Kostic et al. explain in [20], the angle $\beta$ (collector tilted plane angle) determines notably the energy generated by hybrid collectors. Kostic optimizes with a tilt of $45^{\circ}$ in Serbia.

\section{CONCLUSIONS}

In this paper, four solar trigeneration combinations have been compared. Two different solar hybrid (photovoltaic and thermal) panels have been evaluated using two typologies of cooling machines (absorption and adsorption). Seeing all temperatures which have influence in cooling machines, it is more effective to decrease the temperature by one degree in the condenser $\left(T_{K}\right.$, from the cooling tower) than to increase one degree in the generator ( $T_{G}$, provided by collectors) or one degree in the absorber $\left(T_{O}\right.$, chilled heat flow). These temperatures, especially $T_{G}$ will be a decisive parameter when cooling machines are combined with solar hybrid panels.

This work answers the question of which combination between hybrid collectors and cooling machines has better global performance. Comparing the thermal properties on both kind of panels proposed and the COP on each machine, the optimal combination is to use CPVT with absorption machines. The higher thermal efficiency on CPVT panels at 
operating temperatures $\left(T_{G}\right)$ and the higher COP in absorption machines argues the conclusion. On the other hand, if we combine PVT panels with an absorption machine we have better performance than using an adsorption machine. Therefore, to get the best global efficiency, it is more relevant to have higher COPs than the thermal efficiency decrease due to the higher operating temperatures. Comparing both solar technologies, CPVT requires only $55 \mathrm{~m}^{2}$ compared with the $70 \mathrm{~m}^{2}$ required by PVTs.

Analysing the transient simulation we verify that during summer in Madrid, the temperature in the storage tank always exceeds $75^{\circ} \mathrm{C}$ and consequently, no auxiliary system is required. In winter, this solar surface provides enough energy to cover the $79 \%$ of the heating load. In consequence, to integrate absorption machines allows increasing solar surfaces in buildings covering much more energy demands, not only domestic hot water. As future work, authors propose to analyse the maximum solar area that is possible to use avoiding overheats in spring and autumn.

Using one axis tracker (azimuthal), the installation gets more irradiation in the morning and in consequence, the absorption machine starts around 2 hours earlier. This tracking system also allows decreasing the collector surface from $70 \mathrm{~m}^{2}$ to $55 \mathrm{~m}^{2}$. Using CPVT and one axis tracker in a solar trigeneration installation, the optimal tilt to maximize the yearly energy generation is $50^{\circ}$ in Madrid, $65^{\circ}$ in Stuttgart and $75^{\circ}$ in Stockholm.

\section{REFERENCES}

1. Directiva 2002/91/CE del Parlamento Europeo y del consejo de 16 de diciembre de 2002 relativa a la eficiencia energética de los edificios

2. Directiva 2010/31/UE del Parlamento Europeo y del consejo de 19 de mayo de 2010 relativa a la eficiencia energética de los edificios.

3. Desideri U., Proietti S., Sdringola P., Solar-powered cooling systems: Technical and economic analysis on industrial refrigeration and air-conditioning applications, Applied Energy, 86, pp 1376-1386, 2009, http://dx.doi.org/10.1016/j.apenergy.2009.01.011

4. Chow T.T., A review on photovoltaic/thermal hybrid solar technology, Applied Energy, 87, pp 365-379, 2010, http://dx.doi.org/10.1016/j.apenergy.2009.06.037

5. Ibrahim A., Othmanm M.Y., Ruslan M.H., Mat S., Sopian K., Recent advances in flat plate photovoltaic/thermal (PV/T) solar collectors, Renewable and Sustainable Energy Reviews, 15, pp 352-365, 2011, http://dx.doi.org/10.1016/j.apenergy.2009.06.037

6. Assoa Y.B., Menezo C., Fraisse G., Yezou R., Brau J., Study of a new concept of photovoltaic-thermal hybrid collector, Solar Energy, 81, pp 1132-1143, 2007, http://dx.doi.org/10.1016/j.solener.2007.04.001

7. Charalambous P.G., Maidment G.G., Kalogirou S.A., Yiakoumetti K., Photovoltaic thermal (PV/T) collectors: A review, Applied Thermal Engineering, 27, pp 275-286, 2007, http://dx.doi.org/10.1016/j.applthermaleng.2006.06.007

8. Dupeyrat, P., Ménézo, C., Wirth, H., Rommel, M., Efficient single glazed flat plate photovoltaic-thermal hybrid collector for domestic hot water system, Sol. Energy, 2011, http://dx.doi.org/10.1016/j.solener.2011.04.002

9. Dubey S., Tiwari G.N., Thermal modelling of a combined system of photovoltaic thermal (PV/T) solar water heater, Solar Energy 2008; 82: pp 602-612, http://dx.doi.org/10.1016/j.solener.2008.02.005

10. Duffie \& Beckman, Solar Engineering of Thermal Processes, John Wiley \& Sons, New York, 1980. 
11. Mittelman G., Kribus A., Dayan A., Solar cooling with concentrating photovoltaic/thermal (CPVT) systems, Energy conversion \& management, 48, pp 2481-2490, 2007, http://dx.doi.org/10.1016/j.enconman.2007.04.004

12. Bernardo L.R., Peters B., Hakansson H., Karlsson B., Performance evaluation of low concentrating photovoltaic/thermal systems: A case study from Sweden, Solar Energy, 85, pp 1499-1510, 2011, http://dx.doi.org/10.1016/j.solener.2011.04.006

13. Deng J., Wang R.Z., Han G.Y., A review of thermally activated cooling technologies for combined cooling, heating and power systems, Progress in Energy and Combustion Science, 37, pp 172-203, 2011, http://dx.doi.org/10.1016/j.pecs.2010.05.003

14. Núñez T., Nienborg B., Tiedtke Y., Heating and Cooling with a Small Scale Solar Driven Adsorption Chiller Combined with a Borehole System, Task 35

15. Sözen A., Özalp M., Solar-driven ejector-absorption cooling system, Applied Energy, 80, pp 97-113, 2005, http://dx.doi.org/10.1016/j.apenergy.2004.03.005

16. Garcia Casals X., Solar absorption cooling in Spain: Perspectives and outcomes from the simulation of recent installations, Renewable Energy, 31, pp 1371-1389, 2006, http://dx.doi.org/10.1016/j.renene.2005.07.002

17. Bermejo P., Pino F.J., Rosa F., Solar absorption cooling plant in Seville, Solar Energy, 84, pp 1503-1512, 2010, http://dx.doi.org/10.1016/j.solener.2010.05.012

18. Lecuona A., Ventas R., Venegas M., Zacarías A., Salgado R., Optimum hot water temperature for absorption solar cooling, Solar Energy, 89, pp 1806-1814, 2009

19. Frío Industrial, Métodos de producción, E. Torrella, Primera edición. 2010, http://dx.doi.org/10.1016/j.solener.2009.06.016

20. Kostic T., Pavlovic T.M., Pavlovic Z.T., Optimal design of orientation of $P V / T$ collector with reflectors, Applied Energy, 87, pp 3023-3029, 2010, http://dx.doi.org/10.1016/j.apenergy.2010.02.015 